\title{
Philip Knox, Johnathan Morton, and Daniel Reeve (eds.), Medieval Thought Experi- ments: Poetry, Hypothesis, and Experience in the European Middle Ages, Turnhout, Brepols, 2018, vii + 339 pp., ISBN: 9782503576213 . Cloth $€ 90$
}

Reseñado por TRACI PHILLIPSON

Marquette University, Milwaukee, USA traci.phillipson@marquette.edu

This volume represents and interesting and valuable examination of the intersection between the literary and philosophical disciplines of the Middle Ages. It focuses on the use of thought experiments in medieval works of fiction to express and explore philosophical and theological ideas. It consists in an introduction followed by 12 chapters.

In addition to offering a brief overview of the 12 chapters the introduction, by editor Jonathan Morton, explains the purpose of the volume, which is to demonstrate the ways in which Medieval thinkers used fiction and thought experiments to examine philosophical concepts in philosophical, literary, and devotional texts; this is especially important in dispelling the assumption that medieval intellectual life was characterized exclusively by rigidity and formalism. Morton goes on to provide definitions and an assessment of key terms as they were used in the Middle Ages and as they have come to be used today in philosophical and literary disciplines. He explains what constitutes a «thought experiment» for the volume, focusing on the idea that thought experiments are more exploratory and rhetorical than demonstrative. As such they were an important tool, along side logic, in examining religious and philosophical ideas of the day. Additionally, he defines poetry, hypothesis, and experience and details how they function in medieval thought in general and in relation to thought experiments in particular. This is particularly helpful given that the volume seeks to explore these concepts in unique ways and to examine how they interrelate within the context of medieval literature, philosophy, and devotional texts.

In the first chapter, «Thought Experiments with Unbelief in the Long Middle Ages», Marenbon begins with a brief history of the term 'though experiment' with a view towards identifying 2 main types: strict-sense thought experiments, used in philosophical works to establish the truth of a conclusion in a non-argumentative fashion, and loose-sense thought experiments, used more widely and designed to examine a wide range of conclusions before settling on one. Because of their more open view loose-sense thought experiment are generally more richly imagined and are more akin to fictional story telling than the blunt and focused strict-sense thought experiments employed by philosophers. He goes on to discuss various texts which employ thought experiments as a means of examining unbelief, focusing on examples from Abelard, Pomponazzi, and More. Marenbon argues that in Abelard's Collationes we find a portrayal of both Jews and philosophers which is not realistic of 
the time; thus, this constitutes a loose-sense thought experiment where Abelard is able to construct characters for the purpose of exploring ideas and arguments which one would not otherwise encounter. Similarly, Pomponazzi uses a thought experiment of unbelief to probe different philosophical positions around the immortality of the soul in an effort to demonstrate why the Christian position ought to be adopted. Marenbon contrasts the true thought experiments of Abelard and Pomponazzi with More's Utopia, which appears to be a thought experiment but is actually a work which explores various ideas with the necessary feature of moving to establish one of them throughout. Finally, Marenbon reveals that this article is itself a thought experiment, meant to reveal to the reader the problems associated with using the concept of the thought experiments, particularly in the loose-sense, when discussing medieval works; he argues that it introduces unnecessary confusion and we would be better served by taking these texts as they are, without imposing modern notions and categories upon them.

The second chapter, «Can Thought Experiments Backfire? Avicenna's Flying Man, Self-Knowledge, and the Experience of Allegory in Deguileville's Pèlerinage de vie humaine», by Marco Nievergelt, provides a philosophical examination of Guillaume de Deguileville's Pèlerinage de vie humaine with a view towards problematizing its use of Avicenna's famous Flying Man thought experiment to provide empirical evidence of the relationship between the body and the separable soul. Nievergelt argues that the poem is not only meant to present Augustine's view of human life as pilgrimage but is also meant to explore how human beings acquire knowledge and understanding of moral, metaphysical, and theological truth. To demonstrate the ways in which the poem seeks not simply to present a view but to argue for it in literary form Nievergelt offers a careful examination of the ways in which the poem, through the character Reason, explicitly advocates for Augustinian substance dualism and illuminationism and explicitly rejects the dominant Aristotelian views of hylomorphic dualism and abstractionism. Reason uses analogy to explain the Augustinian view of the soul/body relationship. But the pilgrim is unsatisfied and asks to experience the separation of soul from body so that he can grasp the truth directly. This is where the poem employs its own version of Avicenna's Flying Man. The thought experiment as employed in the poem rises to a level of explanatory power not intended by Avicenna. Avicenna identifies 3 methods of communicating knowledge--allegorical/symbolic, indicative, and demonstrative; the Flying Man is part of the second category as it indicates or points towards truths about the human condition but falls short of providing demonstrative arguments for them. But, in the Pèlerinage the Flying Man serves not only as thought experiment but as a kind of experiential or empirical demonstration of Augustinian substance dualism. This, Nievergelt argues, gives rise to logical issues about using sensory experience to demonstrate non-sensory information. This mixing of material/sensory language to describe what is supposed to be a purely rational and immaterial experience highlights the limits of these sorts of thought experiments and the limits of literature when it comes to presenting theoretical truths.

Mishtooni Bose's goal in «Piers Plowman and God's Thought Experiment» is to examine Piers Plowman's particular Christological project, and its use of 'experience' in 
furthering that project, in light of the popular monastic and scholastic theologians of the day. She explains that in the poem the Four Daughters of God, Mercy, Peace, Truth, and Righteousness/Justice, serve as embodiments of the aspects of God's nature, debating about the fate of humanity. The thought experiment of the poem grants the reader a kind of imaginative access to and experience with the thought of God. It is meant to provide a platform from which the reader can contemplate the nature of the Incarnation and the relationship between the mercy and peace of Redemption offered by Christ and the truth and righteousness of humanity's suffering. This reflects a Christological position in the poem in which the Incarnation opens God's to an experience of humanity and a resulting practical knowledge which is in some sense distinct from His perfect theoretical knowledge. Theological questions about God's ability to learn from His experience of the Incarnation were popular at the time. The popular view was that Christ's acquired knowledge could increase through experience but his divine and infused knowledge could not. Bose points out that Thomas Aquinas' view, heavily influenced by Aristotle, was not in line with this consensus. Bose explains that the thought experiment of the poem is exploring these various possibilities without being easily identified with any particular one of them; it uses the debate among the Four Daughters to argue various positions in an imaginative and conceptual framework of its own making.

Alice Lamy's «The Conception of the World in Placides e Timéo» explores the ways in which the author of Placides e Timéo uses a variety of literary tools, including fables, tropes, and thought experiments, to explore philosophical cosmological ideas for a non-philosophical audience. Ultimately, Lamy argues, the work abandons philosophical or speculative argumentation in favor of thought experiment to convey the limits of human knowledge when it comes to understanding divine creation. While the references present in the work are diverse the heavy emphasis on sensation and its role in knowledge attainment demonstrates strong Aristotelian leanings, according to Lamy. In addition to this Aristotelian bent, Placides e Timéo focuses on language and its role in developing understanding and imagination. Ultimately, Placidese Timéo abandons pure speculation in favor of imagination when it comes to attempting to understand the 'marvellous.' Thus, the use of thought experiments is shown to have important imaginative and cognitive impact, helping human beings gain some understanding of truths which would otherwise be beyond their intellectual capacity.

Griffiths uses The House of Fame to explore the idea of dream visions as thought experiments in «'As I kan now remembre': Memory and Making in The House of Fame». She argues that the entire work is an attempt to explore "poetic memory and poetic composition» (p. 123) in an open ended fashion, being more about the writing process itself than about answering any specific questions posed in the text. Griffiths argues that The House of Fame is about memory and its relation to unmediated experience. She traces the ideas of cultural memory, individual memory, and memory of specific words and texts as expressed by the struggle of the poet narrator of the work; she contrasts this with the desire for direct experience which can transcend memory and provide the poet with new inspiration. Griffiths examines both Aristotle's view of memory and John Trevisa's as possible 
sources for Chaucer's understanding of memory and the model of the mind which is expressed and explored in The House of Fame. Chaucer's detailed use of imagery, while certainly literary, also serves the purpose of furthering the idea that the work as a whole is a thought experiment about the nature of the mind in general and of memory in particular.

The sixth chapter, Julia Bourke's «Affective Meditation in Hand Mnemonics and Devotional Texts, from Amor Dei to Fear of Judgement», takes a unique look at thought experiments in the Middle Ages by viewing them through the lens of devotional mnemonics and meditative prose texts. The goal of the paper is to look at several examples of devotional hand mnemonics and meditative prose texts, putting them in their historical context and assessing their use as aids to creating a proper emotional and meditative state. Bourke argues that the mnemonics and meditative scripts were meant to prompt certain emotional and imaginative responses and ultimately reveal truth. Bourke used two primary examples of Cictercian hand mnemoics--the timor Dei/amor Dei set and the meditatio nocturna/meditatio diurna set--and compares them to monastic mediative texts which did not include mnemonics--Anselm's Meditatio ad concitandum timorem, Aelreds De institutione inclusarum and Sawley's Meditationes de gaudiis beatae et gloriosae semper virginis Mariae. The majority of the essay is composed of a careful explanation of the the process of each mnemonic and meditation with an emphasis on the ways in which they use artificial emotional prompting to create a real affective experience. Bourke suggests that the hand mnemonics are precursors to the more well known extended prose meditations.

In «Bonaventure's Thought Experiment: The Use of Synderesis in the Itinerarium mentis in Deum, the Ineffability Topos, and Francis's Stigmata» Gustav Zamore argues that the shift in Bonaventure's use of synderesis between the scholastic Commentary on the Sentences and the mystical Itinerarium mentis in Deum represents a kind of ongoing thought experiment in which Bonaventure experiments with the meaning of the term synderesis to fit the goal of each text. Synderesis goes from being an innate habit of the intellect which provides the «major premises of moral reasoning» (p. 174) in the Commentary to a «suprarational force that unites the soul to God» $(\mathrm{p}, 174)$ in the Itinerarium. Rather than being an abrupt change in meaning, the shift in use represents the development of an idea, according to Zamore. In its moral usage the term is related to the human quest for the moral good (bonum honestum) while in its mystical usages it is part of the quest for the highest good (summum bonum). Zamore proposes that this transition marks the adoption on the part of Bonaventure of the views of Thomas Gallus and it also reflects the need for a means of addressing the ineffability topos, the incommunicability of mystical experience. The use of synderesis in the Itinerarium is particularly placed to communicate the affective nature of mystical experience and the failure of language to capture such experiences; rather, mystical experiences, of which Francis' Stigmata is Bonaventure's prime example, can only be understood by those undergoing them as a way in which the mind is brought into union with God via synderesis.

Chapter 8, «The Art of Rambling: errant Thoughts and Entangled Passions in 
Petrarch's 'The Ascent of Mont Ventoux' (Familiares IV, 1) and RVF 129» by Francesca Southerden, examines two of Petrarch's works with the goal of presenting a concept of rambling as erring but also artistic. Often in Medieval works rambling and curiosity is given a negative connotation and one is shown to eventually stop rambling and find a path to truth. But, in both the "The Ascent of Mont Ventoux' and the earlier RVF 129 Petrarch is moved by desire to continue to wander and, in doing so, to continually encounter himself. Southerden argues that there is particular value is examining these texts, especially «The Ascent», as a thought experiment because in this way the reader can fully embrace the many angles, contradictions, and possibilities of these semi-autobiographical works. In both texts the account is non-linear and rambling; this reflects the rambling nature of exploration depicted within the texts; it also reflects the rambling nature of desire. While most works dealing with desire and ascent resolve in a spiritual transformation, here this is not the case Petrarch experiments with the idea of not giving up one's desires and continuing to encounter oneself rather than God.

In the ninth chapter, «Desire for the Good: Jean de Meun, Boethius, and the "homme devisé en deuz'», Philip Knox, an editor of this volume, examines the relationship between the concepts of desire and the good as they appear in Jean de Meun's Romance of the Rose and Livres de confort, both of which were heavily influenced by Boethius' Consolation of Philosophy. Particular focus is on sexual desire as a natural inclination and its relation to the idea that human beings naturally desire the good. Knox argues that Meun is able, in the Romance of the Rose, to engage in a thought experiment regarding this idea and the problems and contradictions inherent in Boethius' work which he is not able to do in his more demonstrative Livres. This highlights the special ability of literary works to bridge the gap between the demonstrative and the imaginative; poetry allows one to experiment with and emphasize tension and contradiction while leaving them unresolved. To make his case Knox briefly looks at the concept of the good as it appears in Boethius' Consolation, explaining the central claim that all things which have being are good through participation in the goodness of God who is the cause of their being. Within Boethius' work there is tension between the desire for procreative sex as a manifestation of the good to continue being, and the human ability and desire to ascend toward higher goods, rejecting the sensible goods. Meun presents this view faithfully in his Livres. However, in the Romance he is able to examine the issue more closely, drawing out the contradictions at play in claiming that human beings have a natural (and thus good) sexual desire while also claiming that this desire can be seen as bad (when it is not primarily procreative) and that one should will to reject this in favor of a desire for higher intellectual goods. Knox points to key characters in the Romance as particular examples of this tension, arguing that it is only in the poetic context of the Romance that Meun is free to allow these tensions to stand unresolved and to experiment with them.

In the next chapter, «Interpretation all the Way Down: Fabliaux and Medieval Exegesis», Gabrielle Lyons argues that medieval fabliaux, short French moralistic and comedic texts, offer a low-stakes space for experimentation around ideas of interpretation and meaning which were important to scriptural exegesis. It is well established that fabliaux 
show at least some familiarity with higher education and Lyons is taking this a step further by viewing them as a format for examining ideas which were beyond the bounds of more formal and serious religious and scholastic work. First, she provides a basic account of medieval exegesis as grounded in unchanging truth but highly open to myriad interpretations due to the complexity of that truth and the scripture which reveals it. She then presents three fabliaux as examples of places where interpretation can be experimented with freely, being disconnected from the important work of scriptural analysis. In each of the examples we see that the story can have multiple meanings and multiple morals depending upon interpretation. Each has layers of interpretation presented clearly in the text itself as well as layers which the reader can provide with their own interpretations. The 'proper' interpretation is not clear and the main point is the thought experimentation which the fabliaux allow.

The eleventh chapter, "Queer Arts of Failure in Alan of Lille and Hue of Rotelande», written by the volumes third editor, Daniel Reeve, seeks to investigate the relationship between medieval romances and narrative fiction. Reeve argues that romance writers see their work as containing truth under the surface of their fictional accounts, making them thought experiments which can address ontological, epistemological, and ethical questions in ways which texts of direct argumentation cannot. Reeves uses Rotelande's Ipomedon as an example of a romance which not only makes direct use of narrative philosophy, in this case Alan of Lille's De planctu Naturae, but is making some of the same claims in an experimental and experiential way which is necessary to reveal some of the truths about the relationship between language and reality inherent in both texts. First, Reeves provides an account of the difficult to understand philosophical project of the De planctu, arguing that it is not primarily about the immorality of sexual deviancy, as is commonly thought, but about the failure of language and logic to fully embody reality. This is demonstrated not only in the philosophical content of the work but also by its narrative quality. He then goes on to argue that Ipomedon is making a similar claim, relying even more heavily on its nature as a narrative and literary work. In the Ipomedon this is accomplished by the repeated use of detailed but ultimately failed topoi to draw out the romance beyond its expected conclusion; while Ipomedon eventually reaches the expected end of marriage and heterosexual union it does so in a way which calls the desirability of this goal into question. The romance goes on to a lengthy, and unusual for the genre, epilogue in which Hue makes direct reference to the De planctu and suggests that the narrative structure of the poem is even more well suited than its philosophical inspiration to call into question issues of linguistic and logical queerness and failure.

The final chapter, Vincent Gillespie's «Ethice Subponitur? The Imaginative Syllogism and the Idea of the Poetic», calls into questions the traditional medieval claim that poetics pertains, with respect to content, to primarily or only the ethical branch of philosophy. The Poetic, Gillespie argues, does not direct the reader or predicate a particular ethical response or solution, but leaves the imaginative landscape open. The Medieval Arabic commentary tradition, which influenced 12-13th century thought, viewed Poetics as a special branch of logic and the end of the imaginative syllogism of poetry is imagination rather than 
deliberative assent. Thus, it is in itself morally neutral. Poetic provides a framework for the reader to engage in thought experiments, comparing, applying, and considering the representations of the poetry against her own knowledge and ethical values. It is a matter of interpretation rather than simple reception. Some of these Arabic ideas make their way into Western discourse on poetry and become blended with the predominant ethice subponitur view. While one may be expected to achieve a moral understanding though the consideration of poetry in light of already existing ethical understanding, the Poetic itself is still inherently amoral and the focus is imaginative not deliberative.

Overall, this volume offers the reader a valuable opportunity to examine the ways in which the literary, religious, and philosophical genres were used by medieval thinkers. Many texts fit into several genres and have goals which involve providing new ways of encountering religious or philosophical truth. While the particular focus on 'thought experiments' is stronger in some chapters than in others the overall concept of the volume is strong. The sustained and careful examination of the highly integrated and experimental nature of medieval thought and writing makes the volume valuable for those who are interested in this aspect of the study of the Middle Ages. 